Museologisk perle:

\title{
ERINDRING OM TRÆGULV OG TABTE TIDER
}

\author{
Georg Metz
}

\section{I dagbladet Informations weekend nummer den 6.-7. april skrev George Metz} som så ofte for sit "Intermetzo». Causeriet tager sit udgangspunkt i musikoplevelser $i$ Wien, hvis Konzerthaus er affornem, arkitektonisk-akustisk kvalitet (med tragulv, heraf overskriften). Ligesom Odd Fellow-palaets sal i København, som brandte ned for fä år siden. Ingen har indset nodvendigheden af at genopfore Odd Fellow-palaets sal $i$ sin gamle, fornemme stand. Hvorimod man, fortsatter Metz, gerne ofrer millioner pa Sverre Fehns ombygning af Det Kongelige Teater: "Men det er selvfolgelig sjovere at overdakke Tordenskjoldsgadekvarteret med et overdimensioneret halvtag som stationstilbygning til minimetroen», uden nogen kunstneriske nødvendighed. Metz antyder, at det maske har noget at gøre med, at de ansvarlige ikke "har indsigt i de sager de er betroet). (Der hentydes her til Det Kongelige Teaters chef, der kommer fra en departementchefstilling i forsvarsministeriet).

Anderledes $i$ Wien: «Tanke sig: som cheffor Wieneroperaen har østrigerne ansat en mand der har opera som sit eget anliggende og lever af at dirigere symfoniorkestre. Det er $i$ al sin usle enkelthed en strålende idé med fagfolk på topposter $i$ kunsten. Det er det med nødvendigheden, der ikke på kommando opstår naturligt $i$ kulminationen af en departementchefkarriere.» Og så kommer folgende sidespring, som vi vil presentere som en museologisk perle (OS):

«Den, nødvendigheden, oplever man til gengæld i det nyåbnede jødiske museum i Palais Eskeles i Dorothergasse 11 få huse fra Graben. Hovedsagen i museet, som for en halv snes år siden blev iværksat af den daværende Wiener-borgmester Helmut Zilk, er den historiske etage, som til den besøgendes overraskelse blot er et stort nøgent hvidt rum delt op i midten af fire modsat af hverandre lodret nedhængende glasplader. Ellers genstandsløst. På væggen et citat af Walter Benjamin: Das wahre Bild der Vergangenheit huscht vorbei. Nur als Bild, das auf Nimmerwiedersehen im Augenblick seine Erkennbarheit eben aufblitzt, ist die Vergangenheit festzuhalten. 
GEORG METZ

166 (Det sande billede af fortiden flimrer forbi. Fortiden kan kun gribes som et billede, der viser sig i det korte øjeblik, hvor det erkendes og derefter aldrig genses). Citatet står som en understregning af genstandsløsheden i rummet. - Genstandsløst, indtil det går op for en, hvad der dog går for sig i dette forunderlige lokale. Pà glaspladerne viser sig nemlig billederne, der kun kan ses i erkendelsesøjeblikket for derefter at flimre bort. Billeder, holografier, så uhåndgribelige som erindringen. Skygger af jødedommens skæbne i Østrig. Et véråb: I byen var 6 jøder tilbage. Hvorledes skal man bære sig ad med at overleve i en kultur, hvor man på sine fingre kan tælle alle jøderne!

Østrig skilte sig efter Anschluss som bekendt af med sine, myrdede 65.000 jøder fortrinsvis i Mauthaussen og brød sig ikke siden om at tale mere om den sag.

Ét af holografierne forestiller landsbyen. städtlen, hvor det jødiske liv førhen levedes, og hvorfra så mange af dem jo oprindeligt kom og gjorde verden af $\mathrm{i}$ går til hvad den er i dag: Zweig, Mahler, Walter, Hofmannstahl, Benjamin. Et andet af disse forunderlige lysende drømmebilleder af det forgangne er folkene i byen, der ud af denne intethed rækker hænderne ud efter den forbipasserende, vinker, når vi går forbi og forsvinder lige så stille og fatalistisk som de dukkede op og levede den korte tid, der var dem tilmålt på Østrigs jord.

Den materielle side af sagen, de håndgribeligere rester af kulturen er stuvet ovenpå $\mathrm{i}$ museets tagetage. Her henstår $\mathrm{i}$ en samlet blok en række kæmpestore moderne museumsmagasinreoler - af den type man med håndtag på bagsiden kan skubbe frem og tilbage på skinner, sålec' at man kan komme til den enkelte rer 1 .
Her er hensat en nedlagt kulturs forskellige karakteristiske efterladenskaber: Thorakroner, shofaer, lysestager, Dinge... wie man sagt. Netop som museumsstykker, som det dybest set ingen mening har at udstille hver for sig i fine montrer til beskuelse og med skilte og forklaringer. Hvad er der dog at forklare? Således som tingene er berøvet deres mening for altid, idet de mennesker der betjente genstandene ifølge sagens natur blev myrdet fordi de betjente dem, har det en dybere mening at vise deres nuværende stedsevarende meningsløshed ved at lade dem stå i stuvet sammen i mængder, ordnet efter art. På dette loft blandt disse hjemløse konkrete genstande og på baggrund af de Benjaminske tanker om fortidens flimmerbillede er gråden nærliggende for den besøgende. Her går tabet atter op for én. Hvad mere er der at tilføje måske?»

Georg Metz er forfatter og redaktor på Dagbladet Information.

Adr. Information, Store Kongensgade 40,

DK-1264 Kobenhavn $K$.

Fax $+45-33938083$ 